\title{
Borders, Planning and Policy Transfer: Historical transformation of development discourses in the Finnish Torne Valley
}

Word count: 8993

\begin{abstract}
EU spatial policies have become a key institutional context in which to study policy transfer processes in European border areas. These policies are, however, only the most recent part of these transformation processes which raises a need for more historically sensitive approaches (O’Dowd 2010). An historical perspective is important, since border regions are historical processes with particular path-dependent development trajectories and power structures (Paasi 1996). This paper aims to contribute to the discussion concerning the transformation of European border regions by looking at the policy transfer of regional development discourses in the Finnish Torne Valley. The study material consists of strategic development documents produced by the Finnish border municipalities and the municipal-based co-operation organisations from the 1930 s to 2013 . The examination, based on critical discourse analysis, shows that the transformation process is driven by national trends and the dominant planning discourse. Nevertheless, the particular border setting and local discourse on "united Torne Valley" have also intertwined with political and economic processes during different time periods.
\end{abstract}

Keywords: border region, regional planning, discourse, policy transfer, state, Torne Valley 


\section{Introduction}

The EU's internal border regions are considered to be focal sites in which to study state restructuring (Johnson 2009) and the transfer of strategies of regional development. Different time periods are characterised by certain kinds of mind sets, which are dominant, but usually contested discursive "truths" on how regional development should be enhanced (e.g. Moisio 2012). The EU has been an important force in developing and promoting the concepts and best practices of planning during recent decades (Jensen \& Richardson 2004). Accordingly, the EU's spatial policies have formed a key institutional context in which to study the processes of policy transfer. This refers to how particular policies are adopted, implemented and sustained in different contexts (Dolowitz \& March 1996, Prince 2012). A wide set of "Europeanisation" studies exists investigating how the EU's regional policies and ideas are adopted and institutionalised in national institutional structures, how the planning systems are converging across Europe and how common European spaces are being constructed (e.g. Börzel 2002, Jensen \& Richardson 2004). Furthermore, there is a mushrooming set of cross-border cooperation (CBC) studies conducted in the framework of EU regional policies, such as INTERREG, investigating the processes of reterritorialisation and re-scaling through transnational regionalisation and building of cross-border institutions (see e.g. Hansen \& Serin 2010, Knippenberg 2004, Perkman 2002). These studies can be considered as examples of policy transfer studies, as they scrutinise the dynamics of implementing EU policies at the local and regional level.

However, this EU-centricity raises some questions as EU spatial policies and their diffusion are only a relatively recent part of these policy transfer processes, forming only one "layer" of regional development. Policy transfer as a concept is rather new, but as a phenomenon it is not. As Healey (2013) emphasises, the tradition way that planning ideas and knowledge have been circulated from one place to another date back centuries. Today, EU spatial policies create only one dimension of the development discourses at the border regions as they become intertwined and mixed with national- and regional-level policies, as well as with local interests in planners' daily work. O'Dowd (2010: 172) has raised concern about how mainstream border studies have a tendency to emphasise spatial rather than temporal analysis, and are lacking the reflexivity on historical positioning, asking the important questions 'when and where'. Construction of borders and border regions are historical processes (Paasi 1996) and their development should be examined in relation to the changes taking place in state spaces. 
In order to better understand the development possibilities and strategies of border regions, it is important to identify the path-dependent development trajectories. Such investigations make it possible to evaluate under which conditions $\mathrm{CBC}$ is elected as a priority development strategy and when it is opposed. For instance, it is already argued that different nation state- and nationality-related institutions and values often represent obstacles for transnational territorial co-operation (see e.g. Fabbro \& Haselsberger 2009, Prokkola 2008). By examining the transformation of the development and planning work in the context of border regions, it is possible to understand the evolutionary characteristics of restructuring processes as well as regional differences between and within border regions.

The aim of this article is to contribute to this discussion by studying the historical transformation of dominant political development discourses within the Finnish Torne Valley municipalities and municipalbased co-operation organisations. The analysis ranges from the early $20^{\text {th }}$ century until 2013 and it is contextualised in a wider perspective of Finnish state transformation (e.g. Moisio 2012, Jauhiainen \& Niemenmaa 2006, Paasi 1996, Vartiainen 1998). The paper answers the following research questions: 1) How have the dominant development discourses changed in the Finnish Torne Valley since the 1930's? 2) To what extent and in which ways are national and transnational development discourses as well as local/regional discourses connected to the restructuring processes of this border region? 3) How did the understanding of borders and border regions evolved in the context of dominant development discourses?

The Finnish-Swedish border region has gained scholarly attention during the last decade in the Nordic context, but the issue of planning has been neglected. Research has focused on cultural differences created by the border, the border inhabitants' daily practices and attitudes towards the border (Lunden \& Zalamanns 2001), and the recent EU-driven regionalisation, co-operation and governance (Pikner 2008, Prokkola 2008, Prokkola et al. 2015). This paper provides a new perspective on this border region by studying the historical transformation of planning discourses and practices in which local mobilisation is crucial. The paper is structured as follows: the theory chapter scrutinises the relationship between discourse and transformation in the framework of policy transfer and border regions followed by a brief geohistory of the Torne Valley and research design in the next chapter. The empirical analysis is presented with four different periods. Finally, the results and their relevance for further studies are summed up in the conclusion. 


\section{Dominant development discourses, transformation and European border regions}

Contemporary development and planning activities of European border regions are guided by dominant and well-established development discourses. For instance, the local- and regional-level mobilisations that have taken place in recent decades in the border regions reflect several major trends and discourses related to the nation states and their varying politics. The denationalisation of the territorial state thesis and the diversification of governance practices through re-scaling processes are examples of such trends (Jessop 2002: 42). However, these changes are not straightforward and are instead constantly contested by other regional development practices and discourses. In Europe, the neoliberal discourse of 'open' borders and integrated markets and the 'rise of regions' as part of economic competitiveness exists simultaneously with relatively strong institutional structures and discourses of nation states. Additionally, in the border regions, placedependent social and cultural discourses can be found that strongly affect the strategies of regional development and the implementation of different kinds of policy initiatives (Prokkola et al. 2015). As Paasi (1996: 3) writes, the regional transformation of a border region is a context-bound and historically contingent process. Border regions can be considered as discursively contested sites, and with a multidimensional socioinstitutional operational environment they offer a fertile platform to study how policy transfer occurs. Moreover, the meaning of the geography, history and social and institutional environment of places are now seen as important factors through which the process of transfer can be understood (Peck \& Theodor 2001, Prince 2012).

In order to understand how development discourses become hegemonic in particular border regions, it is crucial to acknowledge the relationship between the discourse and transformation. Discourse is defined here as a specific ensemble of ideas, concepts, and categorisations that are produced, reproduced and transformed in a particular set of practices and through which meaning is given physical and social realities (Hajer 1995: 44). The relationship between discourse and social practice is dialectical as discourse constitutes social practice and is at the same time constituted by it (De Cillia et al.1999: 157). Even though such dialectical relationships are highly path-dependent, social research has so far produced only a limited understanding of how discourses are involved in the processes of 'transition' (Fairclough 2010: 506). When examining the relationships between a dominating discourse and material transformation, Fairclough stresses the potential of the cultural political economy approach (CPE), which emphasises the interdependency between material and discursive practices as a part of political and economic processes (see Jessop \& Sum 2013). CPE's advantage in planning policy 
analysis is that it helps expose the strategic momentum of meaning-making (cf. Paul 2012: 383). For instance, how meaning-making matters in regard to economic development when local actors place more value on certain policy objects instead of others. There is a need for more intense examination of meaning making processes as an aspect of political economy, especially in the context of border regions (Varro 2014). Border regions have been acknowledged as particular operational environments with regard to manifestation of organisation of economic functions (Clement 2004) as well as diverse social institutions (Paasi 1996).

When applying the CPE approach in policy transfer analysis, the evolutionary concepts of variation, selection and retention are crucial (cf. Jessop 2004). Through these concepts it is possible to better understand how certain policy discourses become institutionalised and attain hegemony (see also Hajer 2003). Jessop and Sum (2013) note that, in order to become selected from various kinds of variations, a discourse needs to resonate on personal, organisational and institutional levels that are all dependent on discursive and material factors as well as existent power relations. From this perspective, policy transfer is not a top-down process where ideas and policies are transferred from one hierarchical government level to another, rather it is a multilevel and complex process. The effectiveness of the transfer of certain development policies is dependent on local economic and institutional conditions (Peck \& Theodore 2001). As Prince (2012) writes, many times the policies and ideas are tailored to fit in local circumstances which emphasise the role of local agency.

Policy transfer processes manifest changing power relations (Prince 2012). New spatial scales of governance, and policy transfer related to it, give impetus for new development discourses which can gradually become dominant. In order for the re-scaling of governance functions to succeed, the new scale needs to gain a sufficient degree of institutional thickness, that is, formal and informal institutions and the development of an operational environment in which these institutions are firmly in place (Amin \& Trift 1995: 104). In the context of border regions, institutional thickness can be strengthened, for instance through establishment of cross-border organisations and institutions.

Dominant development discourses, which are institutionalised and legitimised in social practices, are often relatively long-lasting, yet always in flux and constantly contested by actual interactions and power relations. Political and economic crisis, however, can change dominant development discourses. As Jessop (2004: 12) notes, "crisis creates the space for determined strategic interventions to significantly redirect the course of events". Crisis also enables processes of "fast policy transfer" where policy makers can demand urgent actions (Peck 2002). This understanding of crisis as a force for change applies also to the European 
border regions. Crisis concerning the economic development of nation states is tightly linked to development practices implemented at national borders or the policies applied at borders especially. In Europe, the opening up of national borders following the disintegration of the Soviet Union and the end of the Cold War caused remarkable changes in relations between nations and attitudes towards border regions (Newman 2011). As old regimes suddenly disintegrated, in many places increased 'openness' of borders prompted an urgent need for new mechanisms to facilitate flows of persons and products across international borders (Clement 2004: 52). The new development discourses adopted after crises are not apolitical but path-shaping processes in which different agencies mediate a new discourse into practice (Jessop 2004: 167).

\section{A brief geohistory of the Torne Valley and the research design}

This study is focused on the Finnish Torne Valley from the perspective of the Finnish state transformation. The common history of the Torne Valley region on the Finnish-Swedish border is an important element of the analysis and, accordingly, it is briefly presented here. This administrative region, today comprising six Finnish municipalities and four Swedish municipalities, has a long cultural and historical background. From the 11th century until the year 1809 - when the border was drawn through the river valley - the valley formed an economic, political and cultural node for this region (Elenius 2008). Following the building of a modern state and strengthening of nationalistic ideology from the late $18^{\text {th }}$ century onwards, peripheral border regions were typically integrated more tightly into the state (Hobsbawn 1990), often causing tension between the core and periphery. Finland gained independence as a consequence of the Russian Revolution in 1917, which strengthened the nation and state building processes (Paasi 1996). The expansion of state governance and strengthening of national ideology integrated the northern border regions more tightly with the southern centres (Paasi \& Prokkola 2008: 18) and also initiated mobilisation of nationalism in the Finnish border areas (Nygård 1984). Interaction and transport across the border were relatively unrestricted with the exception of the First (1914-1918) and Second (1939-1945) World Wars (Paasi \& Prokkola 2008). However, Nordic countries gave up requiring a passport in 1952. Despite relatively free mobility across the border, the role of the border as a geopolitical divider was emphasised, a trend which continued during the Cold War period as well (Koivumaa 2008). 
The following examination of the planning and development discourses focuses on the municipal-based development organisations of the Finnish Committee of Torne Valley Municipalities (FCTVM) founded in 1923 and its binational successor, the Council of Torne Valley (CTV) founded in 1987. This also included three Finnish border municipalities as case studies: Tornio (22 322 inhabitants in 31.12.2014), Ylitornio (4348 inhabitants) and Pello (3676 inhabitants) (see Figure 1). These three municipalities are the original founding members of the FCTVM (Rantakokko 1993). Before municipalities became a more integrated part of the state's planning system, the FCTVM functioned as a lobbyist for local municipalities. The study material consists of altogether 143 documents written in Finnish, including all available key strategic documents related to regional planning; annual reports from the FCTVM and CTV, as well as municipal plans and development plans from studied municipalities (Table 1). The annual reports created by the FCTVM and the CTV form a relatively consistent series from the 1930s until the year 2013 (note1) and offer a good base for transhistorical analysis. The municipal documents are more numerous for recent decades, particularly from the $1980 \mathrm{~s}$ onwards.

The document analysis is based on critical discourse analysis (e.g. Fairclough 2010, Hajer 2003) emphasising the interrelation between language and material development. The analysis begins by identifying how local and regional development have been articulated, and what are the specified objects or branches of trade that need to be developed according to the documents? In addition, an analysis of the key institutional organisations is followed by an examination of local actors' opportunities to affect the development, as well as the relations of the border and border region to such issues. With these variables it was possible to identify the major keywords and terms (cf. Hajer 2003) related to the premises of regional development. Such analysis needs to be placed within the context of wider policy processes (Jensen and Richardson 2004: 63), and the ongoing regional development. In this paper the key terms of the policy documents and the periodisation (see e.g. Jessop \& Sum 2006) are interpreted in relation to the literature on Finnish nation building and state transformation. This periodisation, presented in the following table (see Table 2), summarises how the local border discourses related to regional development have changed.

The transformation of development and planning discourses in the Finnish Torne Valley 
The Republic of Finland gained independence from the Russian Empire in 1917 and the state border became a divider between two nation and state building "projects", while at the local level the border was seen as an obstacle to regional development. From a regional planning perspective, the time period starting from Finland's independence and ending in the 1950s has been labelled an areal state phase (Moisio 2012) in which the development was concentrated in the national southern and western core area while the border regions were significantly less developed (Koljonen 1985). In the annual reports of the FCTVM, agriculture and forestry were considered as the main branches of industry within the Finnish border region until the mid-1950s, and the development actions claimed in documents were primarily related to building of new infrastructure, such as roads, railway and ferries across the border. The lack of adequate road infrastructure was one of the main practical hindrances regarding the utilisation of the natural resources of border regions (Koljonen 1985). From a geopolitical perspective, building new infrastructure was seen as a concrete way to strengthen the territoriality of the new nation state and its security (Paasi 1996, Prokkola 2008). For example, after Finland's independence, the road infrastructure from some of the northern border municipalities was better to Norway than to elsewhere in Finland (Koljonen 1985).

The annual reports of the FCTVM (from 1933 to 1950 's) suggest that the border population and the regional economy were not quite as dependent on the state's actions as they were in later decades. The Finnish government, however, implemented a specific border region policy in the 1920 s which aimed to develop the agriculture of the regions and to engage and integrate the border citizens within the new state structure (Moisio 2012, Paasi 1996). This "border region work" has been seen as the preliminary stage for later comprehensive regional development policies (Koljonen 1985). Surprisingly, this story of state-led border policy was not at all discussed in the analysed documents from the FCTVM. It can be explained by the fact that the economic resources were channelled to local agricultural associations (Koljonen 1985).

The presence of the state was emphasised and problematised, and it was connected to the establishment of regular border controls in the FCTVM's annual reports of the first period. A similar development occurred in several other European border areas after WWI, when many open national borders were closed and became thoroughly "hard" and under constant surveillance (Hurd 2010: 11). The main contradictions between the local and national territorial scale in the early documents were related to the question of how the border region should be governed. The key motives behind the establishment of the FCTVM were to promote and lobby the interests of the border inhabitants and municipalities (Rantakokko 1993). In the documents, state control was 
considered as dominating and a hindrance, and it contradicted local inhabitants' interests and needs related to living in the border region. This unbalanced power relation between "central government" and the local level is presented in negatively charged words and phrases such as "control", "impractical rules" and "border difficulties". There were several references to "close relations across the border" in the annual reports, highlighting how the local discourse underlined the inability of the state government to acknowledge the special nature of this border region, its common cultural background and long tradition of informal interaction across the Finnish-Swedish border. This local discourse was written in the form of a story in order to help people fit their knowledge into the larger policy debate (cf. Hajer 2003: 104-06) and included social practices and argumentation in which the border inhabitants' traditional "border crossing" lifestyle was significant (see Fairclough 2010).

"One of the main aims in the operation of the Committee has been, and in the future will be, related to border difficulties. The border region populations from both countries have had the closest relations with each other dating back to the earliest times. However, despite all this, border crossing is likely regulated nowhere else with so many and so impractical rules as here". (The Annual report, FCTVM 1933)

The possibilities for local actors to influence the development of the border region mainly consisted of lobbying, writing petitions to the central government and organising delegations to Helsinki. The relationship between the key actors involved in planning were primarily vertical and hierarchical, as local actors were subordinated to the central government. This is exemplified by the fact that the FCTVM initially functioned in a thoroughly national setting; co-operation with the Swedish Committee of Torne Valley Municipalities (SCTVM) was uncommon even though issues related to the border were often discussed in the FCTVM's meetings.

In the early documents, the state border and regulations on the mobility of people and goods were identified as a clear obstacle to regional development. In the lobbying and petitions, the local actors used two types of arguments for the removal of border control and regulations: firstly, economic arguments, for example, focused on the harm caused by regulation of timber; secondly, arguments that stressed the common local historical and cultural development of the "united" Torne Valley. Nevertheless, the border setting and the geopolitics of the Finnish state still provided benefits to the local actors. Rantakokko (1993: 7-8) notes that an 
important factor behind the establishment of the FCTVM was the favourable political atmosphere and the importance of state borders after independence in 1917. In addition, the Finnish side of the Torne Valley was underdeveloped compared to the Swedish side, which was an important motivator behind the Finnish state authorities' positive response to the idea of establishing the FCTVM. The asymmetric development of the Torne Valley was also used by state officials as justification for implementing specific border region policies (Numminen 2003).

\section{State border in the shadow of the Finnish welfare state}

The post-World War II development in Finland, between the mid-1950s and mid-1970s, brought considerable changes to the development discourses and practices in the Finnish Torne Valley while the state border was left in the background. These changes were related to the wider political processes in Finland, in which the optimal employment of the state population became a political object of the central government. This is explained firstly by the remarkable change in the economic structure of the Finnish state, one in which modernisation and urbanisation had occurred much later than in many other European countries (Moisio 2012). Secondly, the crisis of WWII was a path-shaping situation which enabled fast policy transfer, where a new development discourse of the welfare state was selected and institutionalised. This top-down Keynesian model of economic organisation (see Pike et al. 2006), the idea that the national economy should be based on heavy industrial investments and regional equity, was realised in Finland through establishing factories and investing in public infrastructure and through comprehensive regional policies such as regional policy laws. The first regional policy law was enacted in 1966 and it stated, that the state government was obligated to allocate resources to underdeveloped regions, that is, to the northern and eastern parts of Finland (Jauhiainen \& Niemenmaa 2006). Investments near border regions have been seen as instruments to achieve national harmony and geopolitical stability (Paasi 1996). Accordingly, Moisio (2102) has labelled this period as a decentralised welfare state phase.

Along with the new national political agendas, new policy concepts were also transferred into the FCTVM's annual reports. Development objects and means referring to comprehensive policy solutions such as "industrialisation", and "policy of regional development" (see Table 2) became a dominating discourse in the annual reports. The discussion about employment focused mostly on northern Finland, thus illustrating the 
prevailing political discourse where northern Finland was formed as a special object for national political action:

"Utilisation of the natural resources of the province and establishing the timber industry is the only valid comprehensive solution for the economic situation in Northern Finland. [...] By stabilising and reorganising the state economy, the general preconditions of production and the competitiveness of the export industry are improved.” (The Annual report, FCTVM 1957)

In northern Finland, the population increased strongly in the late 1950's and beginning of the 1960's primarily because of high birth rate and the resettlement of the evacuated Karelian population after the wars. The population was highest in the county in 1963 (212107 inhabitants) (Lapin Seutukaavaliitto 1974). In addition to strong population growth, technological innovations decreased the number of jobs in agriculture and forestry. This increased the unemployment rate, which was the highest in 1969 when over 10 percent of the county's labour force were listed as unemployed (Majava 1973). In the Torne Valley it was seen strongly as the state's obligation to ensure permanent jobs for its citizenry as self-employment in agriculture became marginalised. From 1960 to 1970 the jobs in agriculture decreased by 53\% in Tornio, 44\% in Ylitornio and 57\% in Pello (Lapin seutukaavaliitto 1975).

"The aim was to actively ensure that there would be enough government work posts (in the Finnish Torne Valley). In this respect, the possibilities turned out to be limited and that is why the unemployment statistics have been alarming in most of the municipalities." (The annual report, FCTVM 1974)

Nevertheless, the Finnish state allocated public investments to the Torne Valley, such as a steel mine in Kolari (1962), building the railway to Kolari mine (1974) and steelworks in Tornio (1976), which improved the unemployment situations at the time (Rantakokko 1993).

It has been noted that during and after a crisis people and politicians are more open to new development ideas as "they seek to give meaning to current problems by construing them in terms of past failures and future possibilities" (Jessop 2004: 167). Rising income levels and public industrial investments supported the government's role as the main actor responsible for regional development (Moisio 2012, see also Vartiainen 1998). This was a pan-Western European trend as the post-war growth had generated optimism about the Keynesian model and the capacity of the national state to govern and manage national macroeconomics and regional development (Pike et al. 2006: 26). However, this optimism was not present in northern Finland or in 
the Finnish Torne Valley, as high unemployment rates had actually decreased the income level during 1960's (Majava 1973). Although, this mind set of the state being responsible for the economic development characterises strongly this period and can be considered as an epistemic notion referring to a regularity in the thinking of a particular period (see Hajer 2003: 104-106). As Jessop and Sum (2013: 405) have emphasised, the greater the number of sites and scales of social organisation through which resonant policy discourses are retained, the greater is the potential for institutionalisation.

In the annual reports of the FCTVM, the question of the national border was not seen as a current issue; the more pressing concern was regional unemployment (see also Rantakokko 1993), which was understood widely as a national problem. Yet from the perspective of transnational regionalisation, this time period was important with regard to the mobilisation of the border region and co-operation between the Nordic countries (Aalbu 1999). This had a direct impact on the Finnish-Swedish border region, the exemption from passport requirements being but one significant example. In the local documents, however, this North Calotte cooperation was mentioned only a few times. Nonetheless, because it was mainly based on ministerial and interregional co-operation, it was not yet strategically important for the border municipalities (cf. Prokkola 2011). However, the border setting was brought out by calling on the state government to take "special" actions and define the Torne Valley as a "special region" with particular needs referring to particular border region policies which took place 1923-1967. The old and new development discourses were manifested in the documents simultaneously, which emphasises the evolutionary nature of the regional transformation.

\section{Diversification of development discourses and utilisation of the border as a resource}

The third period, from the mid-1970s until 1990, is characterised by the rise of local governments and strengthening the horizontal relations between regional- and local-level actors and organisations and also seeing the state border as a resource. In Finland, the municipality became an important government level with the advent of a new state subsidy system, which was an important part of the construction of the decentralised welfare state. Municipalities became a decisive institutional base in this new state system and they became meaningful spaces of life for their inhabitants by providing basic public services (Jauhiainen \& Niemenmaa 2006, Moisio 2012). When considering the power relations between different scalar levels, the state was still the main determiner of regional development until the late 1980s. As late as the 1970s it was still axiomatic in Finland that the central government could govern the development with a uniform governance system. In the 
early 1980s the ideas about a top-down comprehensive planning system were challenged, however, and placeand region-based approaches began to emerge in Finland (Vartiainen 1998), mirroring similar developments elsewhere in Europe (Pike et al 2006). In the annual reports of the FCTVM and municipal plans, which were assigned as compulsory in 1977 for all municipalities (Jauhiainen \& Niemenmaa 2006), branches of trade became more diversified. Greater emphasis began to be placed on new areas of the economy such as tourism and border trade instead of lobbying for 'hard' industrial and infrastructural investments.

This transformation of the rationalities behind the regional development discourse is tightly linked with the debates on territorial restructuring and the transition "from government to governance". The concept of governance refers to those diversified governmental practices organised by various public and private agencies and institutions that do not follow traditional scalar power hierarchies but rather rely on a heterarchy of interconnections (Jessop 1998: 29). Such change is visible in the development documents of the Finnish Torne Valley and it is manifested through adaptation of concepts referring to means of bottom up development such as "municipal strategy", "regional conference," etc. (see Table 2). Secondly, the shift toward multilevel governance and partnership is manifested in the institutionalisation of local cross-border co-operation and new regional organisations that support the regional economy and industries. The dominating development discourse about the need to strengthen horizontal relations in both the national and transnational context is well demonstrated in the following quote:

"As the municipality is a part of a wider regional whole, the decisions concerning it should be fitted as well as possible with the plans on wider areas in co-operation with regional officials, other municipalities and also other communities. Also, co-operation with Swedish municipalities across the border should be developed." (The municipal plan, municipality of Pello, 1983)

The institutionalisation of local $\mathrm{CBC}$ was a decades-long process, and for a long time the interaction between the FCTVM and SCTVM was relatively sporadic. It was not until the early 1980s that "common meetings finally began to be regular" (the Annual report of FCTVM, 1980). When the general development work became more diverse and multidimensional, and when the roles of local governments and regional-level organisations strengthened, the role of the FCTVM as a cross-border organisation became more important.

In 1987 the FCTVM and the SCTVM established the common CTV in order to better meet the special challenges on both sides of the border, especially with respect to the business sector and employment. In the 
new development discourse, business-sector and employment issues were not seen merely as national issues but as common problems for the whole Torne Valley region. Hence, by addressing these issues together, it was envisioned that the region would have better chances for development. When earlier the discourse of united Torne Valley was used in justifications and motivations for unique top-down political actions, now it was tightly linked with economic development. The establishment of the CTV, along with other CBC organisations like Provincia Bothniensis, also established in 1987 by the cities of Tornio and Haparanda, has strengthened the materialisation of this local discourse of a united Tornio Valley region by substantiating the institutional thickness of this transnational operational scale.

In this period, the border was seen more as a resource, as something that could be exploited, first and foremost through the idea of partnership and by combining the development possibilities on both sides of the border. This new idea of co-operation and utilisation of the border setting is well manifested in the following quote:

"The location at the Finnish-Swedish border should be utilised as well as possible in planning by enabling lively interactions across the border. And if possible, the co-operation between different institutions should be considered.” (The municipal plan, The City of Tornio, 1971)

This idea of the border as a resource was additionally manifested in the context of border trade where currency rates affected customer flows remarkably. This is based on an understanding that since the nation state still, for the most part, regulates and coordinates the economic operation inside its borders, local actors can exploit the different economic systems (O'Dowd 2003). For instance, in 1967 when Finland devaluated its currency Swedes started to purchase especially meat and textiles from Finland. In Finland, the net revenue gained from border trade was the highest in 1972-1973 when it was approximately 50 million euros. As for the late 1970's and 1980's Sweden devaluated its currency and border trade changed its course. Finns purchased especially fats and sugar from Sweden that were half-price compared to Finland (Teerijoki 2010).

\section{Borderless Torne Valley - Local and EU's development discourses converge}

The final period identified in the analysis started in the early 1990s and it is defined as a borderless Torne Valley phase in which local and EU's development discourses converge. At that time there was a deep recession in Finland. Along with the collapse of the Soviet Union and Finland's and Sweden's EU membership 
in 1995, the dominating rationalities of regional development policies changed again (Jauhiainen \& Niemenmaa 2006). This phase is strongly characterised by the rise of the information society and competitiveness as dominating development ideas, the strengthening of regions as the basic units of economic competition, and by the rise of project-based development work.

EU membership changed regional policies and structures regarding how development resources were allocated in the countries. The idea of a comprehensive and equal planning system led by the central government questioned already in the 1980s, was now displaced (Vartiainen 1998). The relationship between the regions and nation state in Finland changed especially after the adoption of the so-called Lisbon Strategy in 2000. This EU policy document emphasised the potential of spontaneous development actions in regions and of utilising the region's own endogenic resources (De Bruijn \& Lagendijk 2005), in which know-how and information became both factors and outcomes of production (Moisio 2012: 188-190). Moisio (2012) labels this phase, which started in the early 1990 s, as a decentralised competition state in which the state was moving more towards self-regulating markets. This transition is clearly visible in the analysed documents. Whereas earlier the external factors affecting local and regional development highlighted in the documents were foremost related to the state's policies, now the factors discussed were related mainly to markets and the competitiveness of the region (see Table 2).

In the minutes of the CTV meeting in 1996, the transfer of EU policy rhetoric is notable, as bottom-up development means such as "project", "strategies" and "co-operation" are widely used (see Table 2). The needs of entrepreneurs are portrayed as predominant as is the need to connect firms and entrepreneurs more tightly to the development work, a manifestation of the transition towards self-regulating markets. This was a general trend also at the regional scale in Northern Finland (see Luukkonen 2011). The aims and the role of the CTV increasingly focused on creating favourable operational environments and building horizontal networks between firms and public organisations. Concepts such as "marketing", and "image", linked with the tenets of the information society, became important keywords for creating a general operational environment, especially for tourism development.

In the documents of the CTV, with a good image it is referred primarily to "strong coherent image (of the whole Torne Valley)" (Annual report of CTV, 2011) and it is portrayed as important that the profiling and marketing in tourism is based on the united cross-border region setting: 
"A common history and cultural background, especially a shared language, are evident premises for increase of co-operation. A tourism destination located in two different nations is itself a selling point and an exotic product." (The minutes of CTV meeting, 1999)

Thus, if in the previous phase this development discourse began to be linked gradually with economic development, now, along with development of the information society, it emerges as a key factor of production. This discursive meaning making, giving the story of "unite Torne Valley" a value with regard to regional development, is evolving to be a more integrated part of material development. However, tourism development has not been developed as desired. For instance, in Ylitornio and Pello overnight stays have been decreasing since the beginning of 2000s (Lapin liitto, 2015).

The new economic and institutional environment created by the EU's structural policies offered economic prospects for local governments that were peripheral in the traditional national context (Clement 2004: 53). It is obvious that the EU's CBC policies and Interreg programmes offered a whole new scale of opportunity structures, as they not only provided economic resources but also legitimacy to the $\mathrm{CBC}$ in the region. This is also related to the local discourse about a "united Torne Valley." After joining the EU, this discourse was further entrenched with statements about how the Tornio Valley "performs as a role model (in transnational regionalisation) for many other European border regions" (Annual report of CTV, 2004).

As Jessop and Sum (2013: 404-405) emphasise, the selection and retention of new policy initiatives and ideas are partly dependent on how they resonate with existing cultural narratives, but is not reducible to them alone; it is also dependent on existent institutional structures and agential selectivities. It could be argued that because of the strong local discourse on the harmonious Torne Valley that was firmly institutionalised in the local operational environment (i.e. in the form of co-operation networks, establishment of the CTV, advanced bilateral municipal co-operation between Tornio and Swedish Haparanda, etc.) already before Finland and Sweden joined EU, the policy transfer process and the selection of the European Union's CBC development discourse was relatively uncomplicated.

The way that the $\mathrm{CBC}$ policy discourses and the development resources have been manifested in the municipal documents differs greatly. In Tornio the institutionalisation of $\mathrm{CBC}$ has strengthened slowly since the 1960s and CBC initiatives were already primary strategic projects in the early 2000s and the co-operation with Haparanda was clearly related to economic growth. The most recent project has been the development of a common city centre between Tornio and Haparanda, called an "on the border" project. It was started already 
in the mid-1990s when EU funding from the Interreg IIA programme enabled the initiation of this project. As in Ylitornio and Pello, $\mathrm{CBC}$ was seen more as an opportunity to promote common public services, which were not specified in the documents although these municipalities have a long history of co-operation in health care services and school co-operation, for example (Prokkola 2008). In Pello, CBC and Interreg funding were oftentimes placed last on lists of possible options and strategically important projects, which leaves an impression that $\mathrm{CBC}$ was seen to some extent as a last resort. Although border-related development issues were to some extent present in the documents, the concrete substance nonetheless remained relatively weak. This emphasises the path-dependent characteristics of transformation processes and also the role of evolutionary learning when it comes to retention and institutionalisation of new development discourses (Jessop 2004). In Tornio and Haparanda successful experiences and institutionalisation of the co-operation and the twin city brand strengthened the dominance and retention of this development discourse, manifesting the dialectical relationship between discourses and institutionalised social practices (cf. De Cillia et al. 1999).

As the EU's regional policies offered concrete development resources and possibilities "for even more fruitful cross-border co-operation" (the City of Tornio 1998), the physical border was seen more and more as an economic resource at the local level. Besides, the EU's regional policies and European integration rhetoric have offered economic resources for local actors; they have also certainly strongly influenced the prominence of concepts referring to cross-border regionalisation such as "borderless Torne Valley", "cross-border cooperation", "twin city", etc. The role of policy transfer and the implementation of a new kind of policy rhetoric are obvious in the following quote:

"Tornio, as well as both the Kemi-Tornio sub-region and Torne Valley, including its Swedish side, together form a so-called cross-border region, for which reason it is possible to receive funding for development projects directly from the European Commission through the Interreg community initiative.” (The City Plan, City of Tornio 1993)

The phrase "a so-called cross-border region" is illustrative. In practice, the EU has redefined the concept and operations that local actors have already been implementing for decades. The local actors have simply conformed to the rhetoric of the EU's policy programme in order to gain funding. However, this policy transfer cannot be considered solely as a top-down process, as local actors are using these structures and resources to support their own interests (cf. Prokkola et al. 2015: 111) and utilizing "CBC" as discursive resources (Luukkonen 2011). The Torne Valley region differs from many other European CBRs (Perkman 2002) in that 
a relatively strong local institutional base exists upon which this new policy discourse about CBC is connected and institutionalised. When Finland and Sweden joined the EU the institutionalisation of cross-border cooperation, and the institutional thickness related to it, was more advanced in the CTV and the city of Tornio than in the municipalities of Pello and Ylitornio.

\section{Conclusions}

The aim of this paper has been to investigate the transformation of development discourses in the Finnish Torne Valley by studying how policy transfer has been manifested in local planning documents since the 1930s. A transition from state-led, top-down politics to a more bottom-up, region-based development model where markets strongly affect the development trajectories is evident in the Torne Valley region. The power relations as well as the territorial scale on which the development power is seen to be located are obvious in the development documents, especially when considering local and regional possibilities and means regarding how the region and the municipalities should be developed. These means have become very much regionbased, and the external factors affecting spatial development, which until the late 1980s was linked to the nation state's political actions, have shifted to emphasise market conditions and regional competitiveness.

Policy transfer, how particular methods, concepts and values of regional planning are adopted and implemented in different contexts, is dependent on how particular policies and ideas resonate with place- and path-dependent meaning-making processes. This paper shows clearly how policy transfer is connected with the local-level mobilisation and socio-institutional history of the particular border region in question. Even though the transformation of dominant development discourses and local development practices retells many of the national trends, the border setting has also brought special dimensions to these processes. The institutionalisation of a historical and cultural discourse about a united Torne Valley emphasises both the role of local agency and the path-dependent characteristics of the development of border regions. This discourse runs through the whole set of documented materials and is intertwined with economic and political processes, which illuminate the potential of CPE in studying the discursive dimensions of the political economy (Jessop \& Sum 2013). Already in the 1930s it is emphasised that the nation state did not acknowledge the special characteristics of this border region, and this narrative is used when lobbying state officials. After Finland and Sweden joined the EU, the policy rhetoric and resources related to European border regions strengthened the materialisation and institutionalisation of this development discourse as a part of economic processes and 
production factors, for instance through cross-border tourism and cross-border entrepreneurial co-operation. Along with these processes the discourse on the Finnish-Swedish border has changed: rather than being a mere obstacle for regional development it is now identified as a concrete economic resource.

Development discourses emphasising transnational co-operation offer concrete development possibilities for border regions today, especially in the form of economic resources. However, scholars have argued that one of the key problems of transnational regionalisation is that cross-border regions are often established as top-down technocratic entities in which practical realisation of co-operation objectives oftentimes remains relatively modest (Perkmann 2002). In order to achieve more institutionalised integration and to better understand the factors and conditions affecting these processes, context-sensitive and historical investigations on the development of border regions are important as the highly path-dependent social structures and processes associated with the state borders take a long time to unfold (see O'Dowd 2010: 1033, Paasi 1996). These processes must be studied more widely, and not only in the context of the EU's regional policies, because the EU is not always the exclusive driving force of CBC. As Blatter (2004: 187) emphasises, looking at the borderlands, the "front lines" of territorially demarcated modern states provide numerous opportunities to discover alternative political and economic formations, as the EU's policy frames are too narrow to reveal the broader range of political orders and their trajectories. Since the restructuring and policy transfer processes taking place in the European border regions require the mobilisation of local actors, also the role of local agency should be carefully and critically investigated in further studies.

\section{Notes}

1) There is a gap between years 1990-1995 and between years 1996-1999 analysed documents are minutes of meetings instead of annual reports.

\section{References}

Aalbu, E. (1999) The North Calotte Committee. In Baldersheim, H. \& K. Ståhlberg (Eds) Nordic regionbuilding in a European perspective. pp. 59-68. Ashgate, Aldershot, Brookfield USA, Singapore, Sydney.

Amin, A. \& N. Thrift (1995) Globalization, institutional 'thickness' and the local economy. In Healey, P.,Cameron, S., Davoudi, S., Graham, S. \& A. Madani-Pour (Eds) Managing cities: the new urban context. pp. 91-108. John Wiley, Chichester, Sussex.

Blatter, J. (2004) 'From spaces of place' to 'spaces of flows'? Territorial and functional governance in crossborder regions in Europe and North America. International Journal of Urban and Regional Research $28(3), 530-548$.

Börzel, TA. (2002) States and regions in the European Union: institutional adaptation in German and Spain. Cambridge University Press. 
Clement, N. (2004) Economic Forces Shaping the Borderlands. In Pavlakovich-Kochi, V., Morehouse, B. \& D. Wastl-Walter (Eds) Challenged Borderlands: Transcending Political and Cultural Boundaries. pp. 41-62. Ashgate Publishing Limited, Aldershot, England.

De Cillia, R., Reisigl, M. \& R. Wodak (1999) The discursive construction of national identities. Discourse \& Society 10(2), pp. 149-173.

De Bruijn, P. \& A. Lagendijk (2005). Regional Innovation Systems in the Lisbon Strategy. European Planning Studies 13(8), pp. 1153-1172.

Dolowitz, D. \& D. Marsh (1996) Who Learns What from Whom: a Review of the Policy Transfer literature. Political Studies 44(2), pp. 343-357.

Elenius, L. (2008) Transnational history and language barriers. Luleå University of Technology.

Fairclough, N. (2010) Critical discourse analysis: the critical study of language. Second edition. Pearson, UK.

Fabbro, S. \& B. Haselsberger (2009). Spatial planning harmonisation as a condition for trans-national cooperation: the case of the Alpine-Adriatic Area. European Planning Studies 17(9), pp. 1335-1356.

Hansen, P. \& G. Serin (2010) Rescaling or institutional flexibility? The experience of the cross-border Øresund region. Regional and Federal Studies 20(2), pp. 201-227.

Hajer, M. (2003). A frame in the fields: policymaking and reinvention of politics. In Hajer, M. \& H. Wagenaar (eds.) Deliberative policy Analysis: Understanding Governance in the Network Society. pp.88-112, Cambridge University Press.

Healey, P. (2013). Circuits of Knowledge and Techniques: The Transnational Flow of Planning Ideas and Practices. International Journal of Urban and Regional Research. 37(5), pp. 1510-1526.

Hobsbawn, E. (1990) Nations and Nationalism since 1780: Programme, Myth, Reality. Cambridge University Press.

Hurd, M. (2010) Constructing and challenging Nordic borders: Editor's introduction. In Hurd, M. (Eds) Bordering the Baltic: Scandinavian Boundary - Drawing Processes 1900-2000. pp. 9-26.Transaction Publishers, New Brunswick.

Jauhiainen JS. \& V. Niemenmaa (2006). Alueellinen suunnittelu. Vastapaino, Tampere.

Jensen, OB. \& T. Richardson (2004) Making European Space: mobility, power and territorial identity. Routledge, London.

Jessop, B. (1998) The rise of governance and the risks of failure: the case of economic development. International Social Science Journal 155(1), pp. 29-45.

Jessop, B. (2004) Critical semiotic analysis and cultural political economy. Critical Discourse Studies 1(2), $159-174$.

Jessop, B. \& N-L, Sum (2006) Beyond the Regulation Approach: Putting Capitalist Economies in their Place. Edward Elgar.

Jessop, B. \& N-L. Sum (2013) Towards a Cultural Political Economy: Putting Culture in its Place in Political Economy. Edwar Elgar Publishing Limited, Cheltenham.

Johnson, C. (2009) Cross-border regions and territorial restructuring in Central Europe: room for more transboundary space. European Urban and Regional Studies 16(2), pp. 177-191.

Koivumaa, J. (2008) Geopoliittisra kuvittelua Pohjois-Suomen raja-alueilla. Acta Univerisitatis Lapponiensis 131.

Koljonen, A. (1985) Rajaseututyö: 60 vuotta kehitysaluepolitiikkaa. Nordia Tiedonantoja B:2.

Knippenberg, H. (2004) The Maas-Rhine Euroregion: a laboratory for European integration? Geopolitics 9(3), pp. 608-626.

Lapin liitto (2015) Matkailutilastot. Tornionlaakso joulukuu 2015. http://www.lappi.fi/lapinliitto/julkaisut ja tilastot/matkailu. 8.3.2016.

Lapin seutukaavaliitto (1974) Lapin läänin väestö ja työvoima 1960-2000. Rovaniemi.

Lapin seutukaavaliitto (1975) Lapin maatalous 1959-1969. Rovaniemi.

Lunden, T. \& D. Zalamanns (2001) Local co-operation, ethnic diversity and state territoriality - The case of Haparanda and Tornio on the Sweden - Finland border. GeoJournal 54(1), pp. 33-42.

Luukkonen, J. (2011) Europeanization of spatial planning: Exploring the spatialities of European integration. Nordia Geographical Publications 40(3).

Majava, A. (1973). Lapin muuttoliike - haaste yhteiskuntapolitiikalle. Tornionlaakson vuosikirja 1973. 
Moisio, S. (2012) Valtio, alue, politiikka: Suomen tilasuhteiden sääntely toisesta maailmansodasta nykypäivään. Vastapaino, Tampere

Newman, D. (2011) Contemporary Research Agendas in Border Studies: An Overview. In Wastl-Walter, D. (Eds) The Ashgate Research Companion to Border Studies. pp. 33-48. Ashgate Publishing Limited, Farnham, England.

Numminen, J. (2003) 1920-luvun rajaseutupolitiikka, 1960-luvun kehitysaluepolitiikka, 2000-luvun maaseutupolitiikka. Rajaseutu

Nygård, T. (1984) Akateeminen Karjala-Seura ja Länsipohjan suomalaiset.Tornionlaakson vuosikirja 1984, pp. 46-54. Tornionlaakson Neuvosto/Tornedalsrådet, Tornio.

O’Dowd, L. (2003) The changing significance of European borders. Regional \& Federal Studies 12(4), pp. 13-36.

O’Dowd, L. (2010) From a 'borderless world' to a 'world of borders': 'bringing history back in'. Environment and Planning D: Society and Space 28(6), pp. 1031-1050.

Paasi, A. (1996) Territories, boundaries and consciousness: The changing geographies of the FinnishRussian border. John Wiley \& Sons, Chichester, New York, Brisbane, Toronto, Singapore.

Paasi, A. \& E-K Prokkola (2008) Territorial dynamics, cross-border work and everyday life in the FinnishSwedish border area. Space and Polity 12(1), pp. 13-29.

Paul, R. (2012). Limits of the competition state? The cultural political economy of European labor migration policies. Critical Policy Studies 6(4), pp. 379-401.

Peck, J. (2002) Political Economies of Scale: Fast Policy, Interscalar Relations, and Neoliberal Workfare. Economic Geography 78(3), pp. 331-360.

Peck, J. \& N. Theodor (2001). Exporting workfare/importing welfare-to-work: exploring the politics of Third Way policy transfer. Political Geography. 20:4, 427-460.

Perkman, M. (2002) Euroregions: institutional entrepreneurship in the European Union. In Perkmann, M. \& N. Sum (Eds) Globalization, Regionalization and Cross-border Regions. pp. 103-124. Palgrave Macmillan, Basingstoke, Hants.

Pikner, T. (2008) Evolving Cross-border Urban Networks. PhD dissertation, Department of Geography, University of Oulu

Pike, A., Rodriguez-Pose, A. \& J. Tomaney (2006) Local and Regional Development. Routledge. Abingdon, Oxon.

Prince, R (2012) Policy transfer, consultants and the geographies of governance. Progress in Human Geography 36(2), pp. 188-203.

Prokkola, E-K. (2008) Making bridges, removing barriers. Cross-border cooperation, regionalization and identity at the Finnish-Swedish border. Nordia Geographical Publications 37(3).

Prokkola, E-K. (2011) Cross-border regionalization, the INTERREG III A iniatitive, and local cooperation at the Finnish-Swedish border. Environment and Planning A 43, pp. 1190-1208.

Prokkola, E-K, Zimmerbauer, K. \& F. Jakola (2015) Performance of regional identity in the implementation of European cross-border initiatives. European Urban and Regional Studies 22(1), pp. 104-117.

Rantakokko, M. (1993) Tornionlaakson kuntain toimikunta 1923-1993:Uraauurtavaa maakunnallista yhteistyötä. Tornionlaakson vuosikirja 1993.

Teerijoki, I. (2010) Tornion historia 3, 1918-2000. WS Bookwell Oy, Porvoo

Varro, K. (2014) Spatial Imaginaries of the Dutch-German-Belgian Borderlands: A Multidimensional Analysis of Cross-Border Regional Governance. International Journal of Urban and Regional Research 38(6), pp. 2235-2255.

Vartiainen, P. (1998). Suomalaisen aluepolitiikan kehitysvaiheita. Sisäasiainministeriö, Aluekehitysosasto. 
Table 1. Number of strategic documents from studied organisations

\begin{tabular}{|l|r|r|r|r|r|r|r|r|r|}
\hline Organisation & $1930 \mathrm{~s}$ & $1940 \mathrm{~s}$ & $1950 \mathrm{~s}$ & $1960 \mathrm{~s}$ & $1970 \mathrm{~s}$ & $1980 \mathrm{~s}$ & $1990 \mathrm{~s}$ & $2000 \mathrm{~s}$ & Total \\
\hline FCTVM & 2 & 9 & 9 & 8 & 5 & 10 & 3 & & 46 \\
\hline CTV & & & & & & & 18 & 13 & 31 \\
\hline City of Tornio & & & & & 2 & 3 & 7 & 14 & 26 \\
\hline Municipality of Pello & & & & & & 8 & 9 & 9 & 26 \\
\hline Municipality of Ylitornio & & & & & & & & 14 & 14 \\
\hline Total & 2 & 9 & 9 & 8 & 7 & 21 & 37 & 50 & 143 \\
\hline
\end{tabular}


Table 2. Periodisation based on the document analysis

\begin{tabular}{|c|c|c|c|c|}
\hline $\begin{array}{l}\text { Dominant local } \\
\text { border discourses }\end{array}$ & \multirow{2}{*}{$\begin{array}{l}\text { Border as an obstacle } \\
1933 \text { - mid-1950s }\end{array}$} & \multirow{2}{*}{$\begin{array}{l}\text { Border in the shadow } \\
\text { of the welfare state } \\
\text { Mid-1950s - mid-1970s }\end{array}$} & \multirow{2}{*}{$\begin{array}{l}\text { Border as a resource } \\
\text { Mid-1970s - } 1990\end{array}$} & \multirow{2}{*}{$\begin{array}{l}\text { Borderless Torne Valley } \\
\qquad 1990-2013\end{array}$} \\
\hline $\begin{array}{l}\text { Variables of } \\
\text { local/regional } \\
\text { development }\end{array}$ & & & & \\
\hline $\begin{array}{l}\text { Development } \\
\text { objects, branch of } \\
\text { industries }\end{array}$ & $\begin{array}{l}\text { Agriculture, forestry, } \\
\text { roads, railway, } \\
\text { electrification, } \\
\text { reconstruction, border } \\
\text { crossings }\end{array}$ & $\begin{array}{l}\text { Industrialisation, } \\
\text { regional planning, } \\
\text { railway for ore } \\
\text { transportation, ferry } \\
\text { boats, roads, tourism }\end{array}$ & $\begin{array}{l}\text { Job site, border trade, } \\
\text { shopping tourism, } \\
\text { construction site, } \\
\text { CBC, tourism } \\
\text { development }\end{array}$ & $\begin{array}{l}\text { Tourism, } \\
\text { telecommunications, } \\
\text { internationalisation of firms, } \\
\text { business services, } \\
\text { competitive operational } \\
\text { environment, energy } \\
\text { industry }\end{array}$ \\
\hline $\begin{array}{l}\text { Key/responsible } \\
\text { organisation/actor }\end{array}$ & Central government & $\begin{array}{l}\text { Government, state } \\
\text { officials }\end{array}$ & $\begin{array}{l}\text { Government, regional } \\
\text { officials, planning } \\
\text { officials, municipality }\end{array}$ & $\begin{array}{l}\text { Municipality, EU, Regional } \\
\text { Council of Lapland, } \\
\text { Regional Council of } \\
\text { Norbotten, government, } \\
\text { firms }\end{array}$ \\
\hline $\begin{array}{l}\text { Key local/regional } \\
\text { means to influence } \\
\text { local/regional } \\
\text { development }\end{array}$ & $\begin{array}{l}\text { Petition, proposal, } \\
\text { letter, delegation trip }\end{array}$ & $\begin{array}{l}\text { Letter, statement, } \\
\text { negotiation }\end{array}$ & $\begin{array}{l}\text { Letters, visits, } \\
\text { delegation trips, co- } \\
\text { operation, regional } \\
\text { planning, conference, } \\
\text { project work, common } \\
\text { marketing, municipal } \\
\text { plan }\end{array}$ & $\begin{array}{l}\text { Marketing, know-how, } \\
\text { networking, } \\
\text { internationalisation, } \\
\text { regional co-operation, CBC, } \\
\text { strategic planning, EU- } \\
\text { project, Interreg, municipal } \\
\text { plan, business plan, R\&D }\end{array}$ \\
\hline $\begin{array}{l}\text { External factors } \\
\text { affecting } \\
\text { local/regional } \\
\text { development }\end{array}$ & $\begin{array}{l}\text { Regulation, export } \\
\text { duty }\end{array}$ & $\begin{array}{l}\text { Regulation, special } \\
\text { subsidy, policy for } \\
\text { regional development, } \\
\text { state subsidy system, } \\
\text { unemployment } \\
\text { situation, permanent } \\
\text { job site, comprehensive } \\
\text { solution }\end{array}$ & $\begin{array}{l}\text { Special measures, } \\
\text { unemployment } \\
\text { benefit, devaluation, } \\
\text { municipalities' limited } \\
\text { right of decisions }\end{array}$ & $\begin{array}{l}\text { Image, change in } \\
\text { operational environment, } \\
\text { recession, EU's structural } \\
\text { funds, globalisation }\end{array}$ \\
\hline $\begin{array}{l}\text { Presentation of } \\
\text { border and border } \\
\text { region }\end{array}$ & $\begin{array}{l}\text { Border obstacle, } \\
\text { border passport, } \\
\text { border crossing }\end{array}$ & $\begin{array}{l}\text { Border crossing } \\
\text { difficulties, Torne } \\
\text { Valley as a special } \\
\text { region }\end{array}$ & $\begin{array}{l}\text { Regional planning of } \\
\text { Torne Valley, CBC, } \\
\text { border trade, } \\
\text { difficulties of CBC }\end{array}$ & $\begin{array}{l}\text { Borderless Torne Valley, } \\
\text { borderless markets, CBC, } \\
\text { border city, twin city, cross- } \\
\text { border business co- } \\
\text { operation }\end{array}$ \\
\hline
\end{tabular}


Figure 1. The study region 